\title{
Lenders to the Exhibition
}

Achenbach Foundation for Graphic Arts, the Fine Arts Museums of San Francisco

Autry Museum of Western Heritage, Los Angeles

The Bancroft Library, University of California, Berkeley

California Historical Society, San Francisco

Louis A. Capellino

Crocker Art Museum, Sacramento

M. H. de Young Memorial Museum, the Fine Arts Museums of San Francisco

Garzoli Gallery, San Rafael, California

The Gilcrease Museum, Tulsa, Oklahoma

Eldon and Susan Grupp

F. E. Keeler III

Dr. Oscar and Trudy Lemer

James and Susan McClatchy

Everett Millard

Museum of Fine Arts, Boston

The National Cowboy Hall of Fame and Western Heritage Center, Oklahoma City, Oklahoma

National Museum of American Art, Smithsonian Institution, Washington, D.C.

Oakland Museum of California

Hideko Goto Packard

Mr. and Mrs. A. R. Phillips Jr.

Post Road Gallery, Larchmont, New York

Private collections

Sacramento Archives and Museum Collection Center

Santa Barbara Historical Society

Santa Barbara Museum of Art

Southwest Museum, Los Angeles 
This page intentionally left blank 


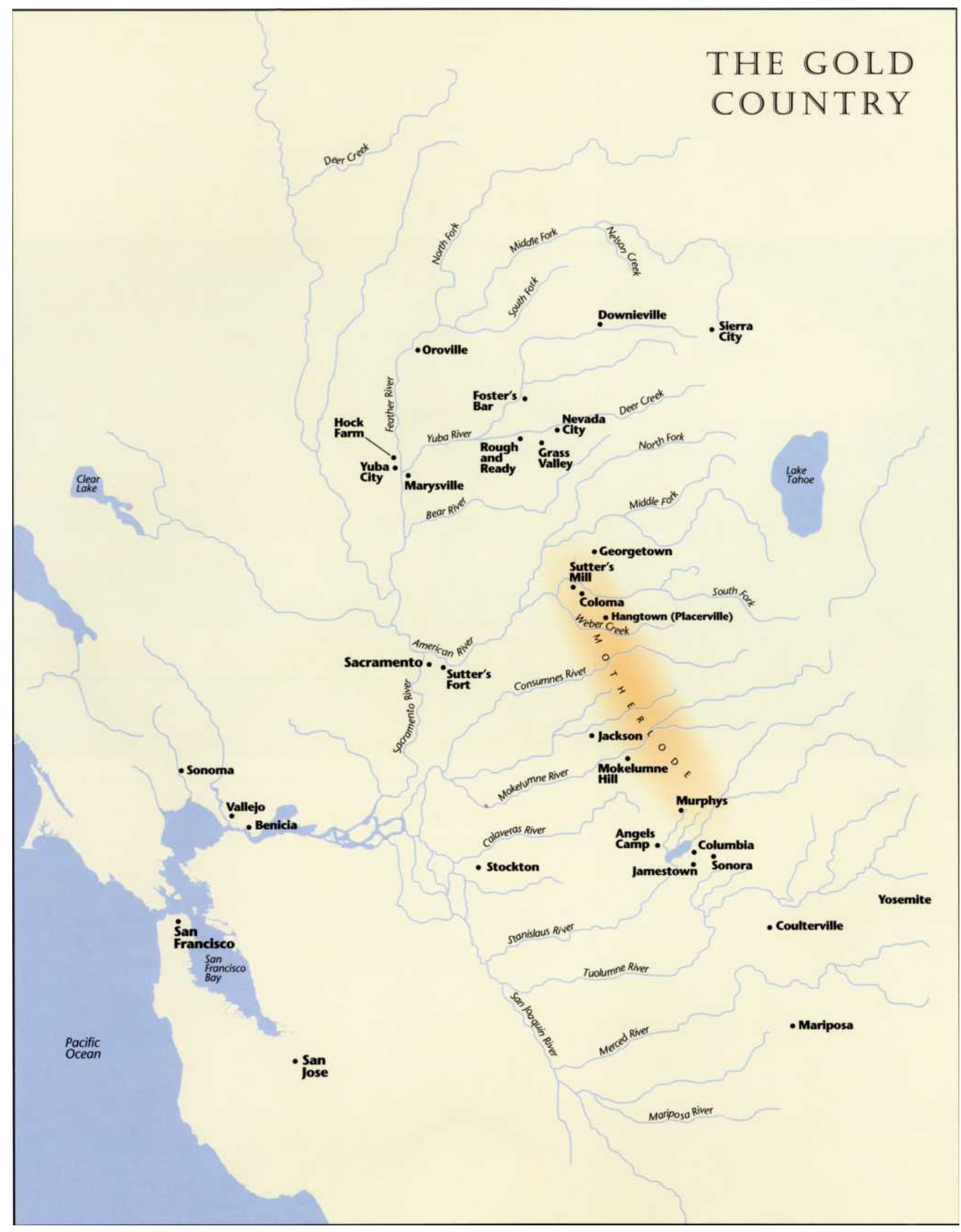




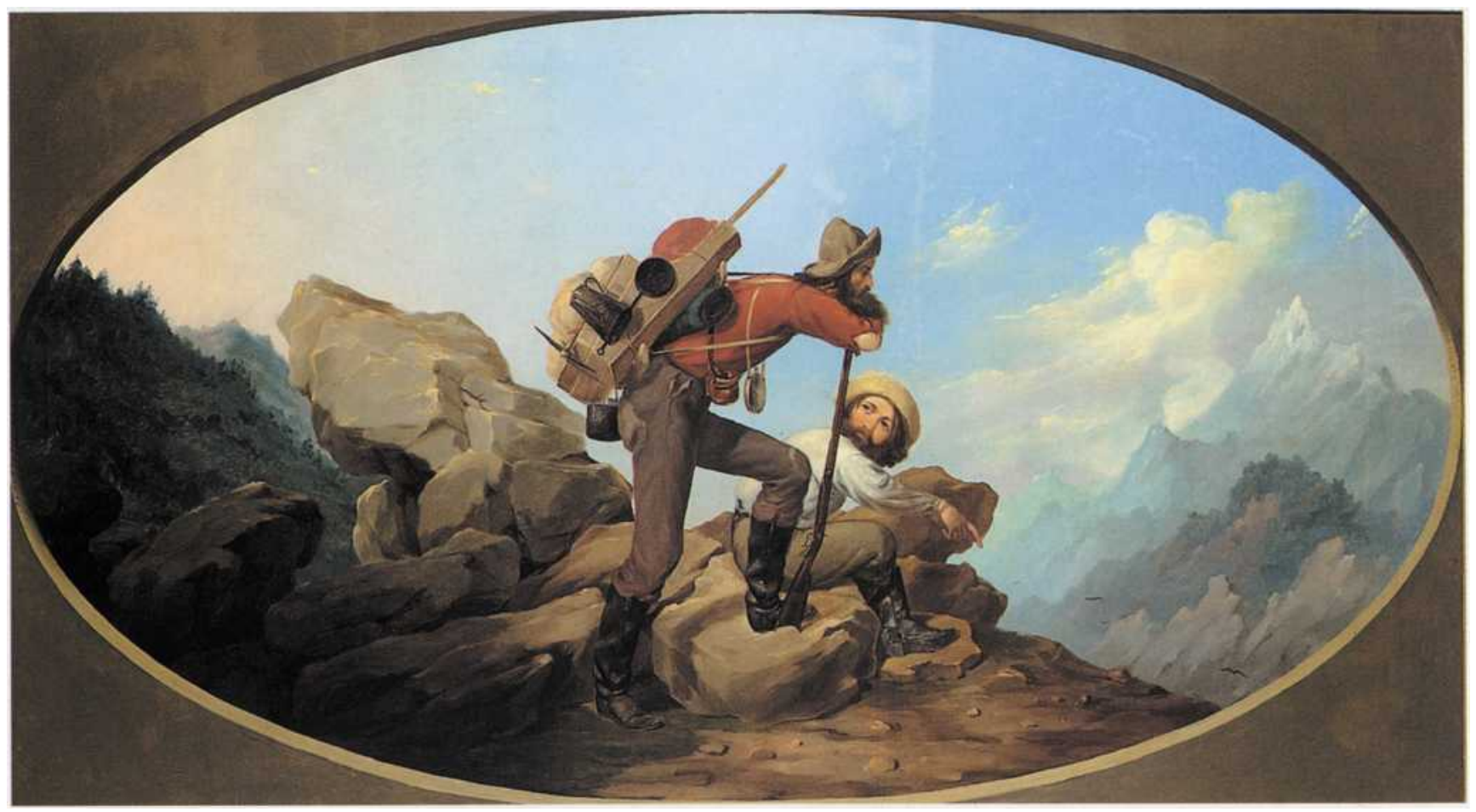

FIG. I. E. Hall Martin, Mountain Jack and a Wandering Miner, 1850 . Oil on canvas, $39^{1 / 2} \times 72$ in. Oakland Museum of California, gift of Concours d'Antiques, Art Guild. 